\title{
Effectiveness of Toothpony (Gazza minuta) protein hydrolysate on reducing oil uptake upon deep-frying
}

\author{
${ }^{1 *}$ Zainol, M.K., ${ }^{1}$ Tan, R.C., ${ }^{1}$ Mohd Zin, Z., ${ }^{2,3}$ Ahmad, A. and ${ }^{4}$ Danish-Daniel, M. \\ ${ }^{1}$ Faculty of Fisheries and Food Science, Universiti Malaysia Terengganu, 21030, Kuala Nerus, Terengganu \\ ${ }^{2}$ Faculty of Science and Marine Environment, Universiti Malaysia Terengganu, 21030, Kuala Nerus, \\ Terengganu \\ ${ }^{3}$ Institute of Tropical Biodiversity and Sustainable Development, Universiti Malaysia Terengganu, 21030 \\ Kuala Nerus, Terengganu, Malaysia \\ ${ }^{4}$ Institute of Marine Biotechnology, Universiti Malaysia Terengganu, 21030 Kuala Nerus, Terengganu, \\ Malaysia
}

\begin{abstract}
Article history:
Received: 21 November 2019

Received in revised form: 2

January 2020

Accepted: 15 January 2020

Available Online: 9 February 2020
\end{abstract}

Keywords:

Fish protein hydrolysate,

Deep-fat frying,

Toothpony fish (Gazza minuta)

DOI:

https://doi.org/10.26656/fr.2017.4(3).392

\begin{abstract}
Toothpony (Gazza minuta) is not typically used for human consumption due to its small size and low meat content, which is widely used as a fish meal. It is stated to be high in protein content and may be suitable for fish protein hydrolysate (FPH) production. Deepfat fried foods contain significant amounts of fat, in some cases up to one-third of the total food weight after frying. Toothpony FPH with low oil-binding ability may reduce the amount of oil consumed by deep-fried products. The objective of this research was to measure the physicochemical properties of Toothpony FPH and its utilisation in reducing the oil intake of deep-fried food. Toothpony FPH was obtained using the enzymatic method successfully. Batter formulations are prepared by adding $0 \%, 2 \%, 4 \%, 6 \%$ and $8 \%$ of Toothpony FPH into the sample mixtures. The present study indicates the degree of hydrolysis of Toothpony FPH determined by trichloroacetic acid (TCA) method was found to be $98.02 \%$. Toothpony FPH's molecular weight distributions ranged from 7 to $175 \mathrm{kDa}$ and FTIR's transmission spectrum indicated the presence of amide I and amide II compounds $\left(1654\right.$ and $\left.1535 \mathrm{~cm}^{-1}\right)$. Oil binding capacity of Toothpony FPH was found to be low, which was $1.9 \mathrm{~g}$ oil $/ \mathrm{g}$ protein. This study indicated that $4 \%$ of Toothpony FPH produced the optimum amount to be incorporated in batter in order to best reduce oil uptake. In sensory evaluation, deep-fat-fried squid incorporated with $8 \%$ of Toothpony FPH showed the highest acceptance in all attributes, which were colour, crispness, oiliness, taste and overall acceptability. This approach offers the potentials use of Toothpony fish FPH for the production batter formulation which is efficient in the reduction of oil uptake.
\end{abstract}

\section{Introduction}

Malaysia produced 1.75 tons of marine fishing in 2008 , which accounted for $80 \%$ of total fish production, and it was estimated that $30 \%$ of caught fish were discarded as trash fish (DoF Annual Fisheries Statistics, 2008). Toothpony (Gazza minuta) (Figure 1) was reported to be one of the main trash fish harvested (Hasan and Halwart, 2009). The toothpony fish were not popular for human consumption due to its small size and low meat content. It is commonly being used as fish meal (Klomklao et al., 2013). Surprisingly it has a high protein content $(19.3 \%)$ and could be suitable for the production of fish protein hydrolysate (FPH). FPH from fish proteins can be considered good dietary supplements such as bioactive compounds and can be easily absorbed and used for different metabolic activities (Nesse et al., 2011). The by-product produced by the fish processing industry contains a good amount of protein-rich material and can be processed into hydrolysates of fish protein (FPH) (Chalamaiah et al., 2012). FPH can be used as active ingredients in various foods because they have numerous essential and special properties such as water holding capacity, emulsifying properties, foaming properties and oil binding capacity (Chalamaiah et al., 2010).

Deep-fat frying is one of the oldest and most widely used methods of cooking to make delicious and crispy foods (Pedreschi and Moyano, 2005). It involves the 
immersing of food in edible oils heated above the water boiling point and creates the desired quality characteristics namely taste, texture, odours and colour (Pedreschi, 2012). Coating products using deep-fat frying batters is a common and popular process used in the preparation of deep-fried products. Batters should not only add value to the product by controlling the loss of moisture and thus the uptake of oil during frying (Dogan et al., 2005). The efficacy of a batter as a barrier to the absorption of lipids by food is determined by its mechanical and barrier properties, which depend on its composition and microstructure, and the substrate characteristics (García et al., 2008). A typical batter formula consists of critical ingredients of wheat flour, maize flour and a leavening agent. Proteins can be added to the batter as functional ingredients by forming lipid barriers (Kulp and Loewe, 2011).

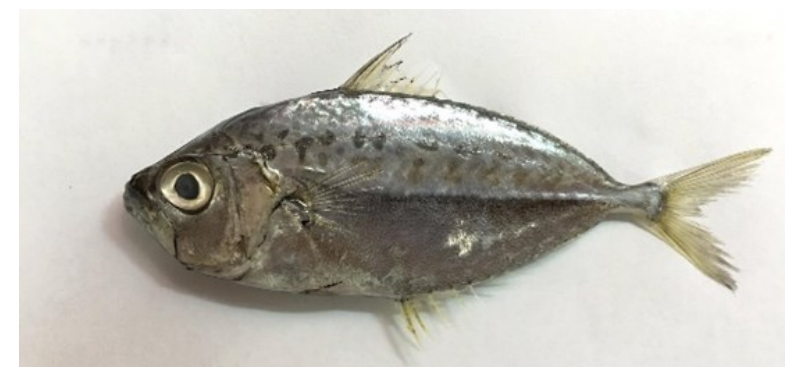

Figure 1. Toothpony fish (Gazza minuta)

The recent trend towards the reduction of fat content in fried foods contributes to the development of low-fat products using different formulations of batter ingredients (Dogan et al., 2005). FPH has been successfully tested for incorporation into various food systems such as cereal products, fish and meat products, desserts and crackers (Kristinsson and Rasco, 2000). This phenomenon has attracted the attention of the food industry to use the low oil-binding FPH as a potential application to minimize the consumption of deep-fried food (He et al., 2015). Nevertheless, there is little knowledge about the introduction of FPH into the batter and its effect on the absorption of oil in batters. Most of the barriers used in the commercial production of fried foods are protein-based (Hau et al., 2018). The aim of this research was to develop a new concept product containing Toothpony fish FPH in the batter and to determine the physicochemical properties of the fried product in order to visualize it as a potential good source of protein that could later be transformed into a more functional product.

\section{Materials and methods}

Toothpony (Gazza minuta) were purchased from Jeti Pulau Kambing, Kuala Terengganu, Terengganu, Malaysia. The guts and head of Toothpony were removed and the sample was cleaned. The sample was then homogenized using food processor (Panasonic, Malaysia). Enzymatic extraction was carried out using the modified method of Hau et al. (2018). A total of 50 $\mathrm{g}$ of fish meat was deactivated at $90^{\circ} \mathrm{C}$ for $10 \mathrm{mins}$. The sample was then mixed with $100 \mathrm{~mL}$ of buffer at $\mathrm{pH} 8$. A total of $50 \mathrm{~g}$ of homogenized sample was mixed with 500 $\mathrm{mL}$ of water in a $1000 \mathrm{~mL}$ beaker and heated using hot plate (Favorit, Malaysia) at $90^{\circ} \mathrm{C}$ for 10 mins. Next, 50 $\mathrm{mL}$ of $1 \mathrm{M}$ potassium phosphate buffer $(\mathrm{pH}$ 7.5) was added to the fish (ratio of 1:1 between fish and buffer) and the mixture was mixed thoroughly. The $\mathrm{pH}$ of the mixture was set at 7.5. After hydrolysing the protein for $3 \mathrm{hrs}$, the mixture was placed on hot plate which operating at $90^{\circ} \mathrm{C}$ for 5 mins to inactivate the enzymes. The mixture was then cooled and centrifuged at 10000 rpm for 20 mins. Freeze drying was conducted using a Labconco Freeze Dryer -Stoppering tray (USA) operated at $-54^{\circ} \mathrm{C}$ while the vacuum was set at 0.25 mbar.

\subsection{Proximate composition of Toothpony fish}

The moisture, ash, fat and crude protein content of the Toothpony fish were determined according to AOAC (2012) standard procedures. Analyses were carried out in triplicates and calculated on dry weight basis using AOAC methods (AOAC, 2012).

\subsection{Determination of degree of hydrolysis}

Degree of hydrolysis of Toothpony fish lyophilized hydrolysate was determined using trichloroacetic acid (TCA) method, which has been described by Hoyle and Merritt (1994). A total of $2 \mathrm{~g}$ of lyophilized hydrolysate was needed to carry out this analysis. One gram of lyophilized FPH powder was determined through Kjedahl method (AOAC, 2012). As for the 10\% TCA soluble nitrogen determination, $1 \mathrm{~g}$ of lyophilized Toothpony fish protein hydrolysate powder was added into $10 \mathrm{~mL}$ distilled water, respectively. Then, $10 \mathrm{~mL}$ of $20 \%$ TCA was added into the sample and mixed by vortex. The sample was left to stand for $30 \mathrm{mins}$, to allow protein precipitation. The sample was then centrifuged at $8000 \mathrm{rpm}$ for 5 mins (High Speed centrifuges 1580R, Cryozen Co, Ltd, Korea). Protein content in the collected supernatant by-product using Kjedahl method (AOAC, 2012). The protein content was calculated using the formula below:

$$
\begin{aligned}
& \% \text { nitrogen }=\frac{\mathrm{ml} \mathrm{H}_{2} \mathrm{SO}_{4}(\text { sample }- \text { blank }) \times 1.4}{\text { weight sample }(\mathrm{g}) \times 1000} \times 100 \\
& \% \text { crude protein }=\% \text { nitrogen } \times 6.25
\end{aligned}
$$

The degree of hydrolysis was calculated by using the formula below:

Degree of hydrolysis $(\%)=\frac{10 \% \text { TCA soluble nitrogen in the sample }}{\text { Total nitrogen in the sample }} \times 100$ 


\subsection{Determination of FPH molecular weight}

The Toothpony FPH were analysed for sodium dodecyl sulfate polyacrylamide electrophoresis (SDSPAGE) analysis based on the method Zainol et al. (2014) with some modification. SDS-PAGE gel used consisted of 2 layers of acrylamide gels namely resolving gel and stacking gel. Resolving gel layer consisted of $950 \mu \mathrm{L}$ of $40 \%$ bisacrylamide: acrylamide (19:1), $1250 \mu \mathrm{l}$ of $3 \mathrm{M}$ Tris 5\% SDS, $1120 \mu \mathrm{L}$ RO-water, $400 \mathrm{~mL}$ Glycerol, 2 $\mu \mathrm{L}$ TEMED and $19 \mu \mathrm{L}$ of ammonium persulphate. The Toothpony FPH sample was diluted in $5 \%(\mathrm{w} / \mathrm{v})$ and mixed with $1: 1(\mathrm{v} / \mathrm{v})$ ratio loading buffer. The mixture was cooked in $90^{\circ} \mathrm{C}$ water bath for 10 mins and cooled immediately prior to loading. Sample and protein standard volumes of $25 \mu \mathrm{L}$ are loaded into individual wells and operated using a discontinuous tristricine buffer with $25 \mathrm{~mA} / \mathrm{gel}$ constant current and $100 \mathrm{~V}$ constant voltage for $1 \mathrm{hr}$. After electrophoresis, proteins were visualized by $0.1 \%$ (w/v) Coomassie blue G250 staining and destaining by soaking in several changes of $40 \%(\mathrm{v} / \mathrm{v})$ methanol and $10 \%(\mathrm{v} / \mathrm{v})$ acetic acid until a significant clear bands were obtained. Broad protein markers (11 to $245 \mathrm{kDa}$ ) were used for molecular weight comparison.

\subsection{Determination of functional groups}

The functional groups of Toothpony FPH were determined using FTIR Transmission (Nicolet iS10, Thermo Scientific, US) in which $4 \mathrm{mg}$ of Toothpony fish protein hydrolysate powder was mixed with $200 \mathrm{mg}$ of $\mathrm{KBr}$ (1:50). The mixture was homogenized using agate mortar and pestle and then it was pressed into pellet (1-2 $\mathrm{mm}$ thick films) with a 15 -ton hydraulic press. The FTIR spectra were obtained from wavenumber of 600 to 4000 $\mathrm{cm}^{-1}$ during 64 scans with $2 \mathrm{~cm}^{-1}$ resolution. The resulting spectrum represents the molecular absorption and transmission which then create a molecular fingerprint of the sample (Durga Maha Lakshmi et al., 2014).

\subsection{Determination of oil uptake}

Five batter mix was formulated (Table 1) with the addition of four different amount of fish protein hydrolysate $(0 \%, 2 \%, 4 \%, 6 \%, 8 \%)$ into each formulation and the other one batter formulation was kept constant in which no FPH was added in the formulation. The batters were used to coat squids $(3 \mathrm{~cm}$ $x 3 \mathrm{~cm}$ ). The coated squids were then deep-fried in palm oil for 3 mins at $180^{\circ} \mathrm{C}$, was drained and cooled. Then, the batter crust was peeled off from the squids and the oil was extracted using Soxhlet extraction method.

Oil-uptake was measured with a slight modification by a method described by Wasswa et al. (2007). In a 50
$\mathrm{mL}$ centrifuge tube, a total of $0.5 \mathrm{~g}$ of Toothpony FPH powder sample was added to $9 \mathrm{~g}$ of palm oil, mixed with a vortex mixer for $1 \mathrm{~min}$, and then centrifuged at room temperature at $2000 \mathrm{x} g$ for 30 mins. The weight of the extracted oil was determined from the hydrolysate. The difference between the oil weights derived from the hydrolysate and the initial palm oil $9 \mathrm{~g}$ was the oil weight consumed by a sample of $1 \mathrm{~g}$. The oil consumption was measured as the quantity of oil consumed by the samples.

Table 1. The ingredients in batter powder formulation

\begin{tabular}{lccccc}
\hline \multicolumn{1}{c}{ Ingredients } & \multicolumn{5}{c}{ Percentage of ingredients (\%) } \\
\hline Fish protein hydrolysate & 0 & 2 & 4 & 6 & 8 \\
Wheat flour & 15.2 & 13.2 & 11.2 & 9.2 & 7.2 \\
Rice flour & 80 & 80 & 80 & 80 & 80 \\
Sodium chloride & 3 & 3 & 3 & 3 & 3 \\
Sodium bicarbonate & 1 & 1 & 1 & 1 & 1 \\
Disodium pyrophosphate & 0.8 & 0.8 & 0.8 & 0.8 & 0.8 \\
\hline
\end{tabular}

* Batter powder was mixed with water in the ratio of $1: 1$

\subsection{Texture profile analysis}

Texture profile analysis was performed using Dogan et al. (2005) method with a slight modification. Texture of the samples' crust was analysed in terms of hardness and crispness. These were measured in the fried samples using texture analyser (TA.XT. plus Stable Micro System Ltd., US). A load cell of $50 \mathrm{~N}$ was used. A conical probe was attached to the instrument for the penetration test. The instrument was set to a speed of 55 $\mathrm{mm} \mathrm{min}^{-1}$ for $25 \%$ penetration of a conical probe into the fried sample.

\subsection{Colour profile analysis}

The crust colour of fried squid was determined by using colorimeter (CR-300 Chroma Meter, Konica Minolta, Japan), working with cool white light (D65) and $2^{\circ}$ to know Hunter $L^{*}$ (lightness), $a^{*}$ (redness), and $b^{*}$ (yellowness) values. The instrument was calibrated using white tile provided. Instrument was directly put on the surface of each sample at three different points. $\mathrm{L}^{*}, \mathrm{a}^{*}$ and $b^{*}$ values of each sample was recorded.

\subsection{Sensory evaluation}

A fresh batch of fried squid was used for sensory studies. The fried squid was subjected to sensory evaluation for colour, odour, oiliness, crispness, and overall acceptability. The sensory evaluation was carried out by thirty panellists using 7-point Hedonic scale. The mean score for each attribute was reported.

\subsection{Statistical analysis}

Analysis of oil uptake was conducted triplicate and 
the statistical analysis was carried out using MINITAB 14 statistical software packaged. The results were expressed as mean \pm standard deviation. The significant difference at $(\mathrm{p}<0.05)$ was performed by one-way analysis of variance (ANOVA) and Fisher's Least Significant Difference (LSD) test.

\section{Results and discussion}

\subsection{Proximate composition of Toothpony fish}

Chemical analysis was carried out to determine the chemical composition (protein, fat, moisture) of Toothpony fish raw sample (Table 2). The raw Toothpony fish sample contained $16.08 \%$ of protein, $4.41 \%$ of fat and $77.51 \%$ of moisture. However, the chemical compositions recorded in this study were slightly lower than the data reported by Klomklao et al. (2013). They reported that Toothpony fish muscle contained $83.32 \%$ of protein (dried weight basis), $9.32 \%$ of fat and $80.01 \%$ of moisture. The difference in nutritional composition might be due to environmental factors. Nutrient profiles of fish were reported to be varied with the environment and it was more unmanageable in the wild. The nutrient profiles of wild fish could be even more variable than those of their farmer counterparts (Perschbacher and Stickney, 2017).

Table 2. Proximate composition of Toothpony fish edible flesh

\begin{tabular}{|c|c|}
\hline \multicolumn{2}{|c|}{ Percentage of Toothpony FPH powder (\%) } \\
\hline Moisture content (\%) & $77.51 \pm 2.76$ \\
\hline Protein (\%) & $16.08 \pm 0.35$ \\
\hline Fat content $(\%)$ & $4.41 \pm 0.35$ \\
\hline Ash (\%) & $2.0 \pm 0.08$ \\
\hline Degree of hydrolysis (\%) & $98.02 \pm 0.34$ \\
\hline
\end{tabular}

Mean value with same superscript letter showed no significant different $(\mathrm{p}<0.05)$.

\subsection{Determination of degree of hydrolysis}

Table 3 shows the Toothpony fish protein hydrolysate $(\mathrm{FPH})$ contained $38.02 \%$ of protein. It was expected that Toothpony FPH to exhibit a higher value of protein than that of in raw sample $(16.08 \%)$. Klomklao et al. (2013) have reported higher protein content (89.02\%) in Toothpony FPH. This could be due to the fact that Klomklao et al. (2013) have used viscera extract from hybrid catfish to hydrolyse Toothpony FPH instead of Alcalase enzyme. However, the result was in contrary with findings reported by Venuste et al. (2013), who reported that Alcalase treated hydrolysates were significantly higher protein content because of high solubility. The high protein content of FPH demonstrates its potential use as protein supplements for human nutrition (Chalamaiah et al., 2012).

Degree of hydrolysis (DH) of Toothpony FPH was determined using trichloroacetic acid (TCA) method. DH of Toothpony FPH was illustrated in Table 3. DH of Toothpony FPH was $98.02 \%$. The high value of DH was probably due to the Alcalase enzyme used in the extraction of Toothpony FPH. Alkaline proteases have reportedly a greater capability to solubilize fish protein compared to neutral and acidic proteases (Sugiyama et al., 1991). Alcalase, which is one of the alkaline proteases, is prominently used in the hydrolysis of proteins from fish due to its high $\mathrm{DH}$ in a relatively short time (Kristinsson and Rasco, 2000). However, DH was reported to have an effect on the physicochemical properties of FPH (Harun et al., 2017), which could lead to a low oil uptake.

\subsection{SDS- PAGE analysis of Toothpony FPH}

Figure 2 shows the characterisation by SDS-PAGE of Toothpony FPH's molecular weights (MW). The Toothpony FPH exhibited molecular weight lower than $175 \mathrm{kDa}$ which and gelatin from catfish skin $(<200 \mathrm{kDa})$ (Mahmoodani et al., 2014). Differences are found between Toothpony FPH molecular weight and catfish skin gelatin may be due to the various species and part of the fish. The hydrolysate showed multiple bands that could result from larger proteins in the raw material that the enzyme does not fully hydrolyze (Souissi et al., 2007). Several studies have shown Alcalase enzyme's ability to produce peptides of low molecular weight (MW) at a high degree of hydrolysis (Liaset et al. 2000). According to Roslan et al. (2014), alcalase has shown protein cleavage, leading to the production of small peptides. Hence, the presence of low molecular weight bands in Toothpony FPH in the present study could result in the production of FPH with useful chemical properties.

Table 3. The oil binding capacity, fat uptake, hardness and crispness values of deep-fat-fried squid batter crust incorporated with different amount of Toothpony FPH

\begin{tabular}{lccccc}
\hline Amount of Toothpony FPH in Batter & $0 \%$ & $2 \%)$ & $4 \%$ ) & $6 \%$ ) & $8 \%$ ) \\
\hline Oil Binding Capacity (g oil/g protein) & $8.91 \pm 0.16^{\mathrm{a}}$ & $4.52 \pm 0.13^{\mathrm{b}}$ & $2.9 \pm 0.21^{\mathrm{c}}$ & $1.91 \pm 0.06^{\mathrm{d}}$ & $2.5 \pm 0.16^{\mathrm{c}}$ \\
Oil uptake (\%) & $27.22 \pm 0.77^{\mathrm{a}}$ & $23.54 \pm 2.52^{\mathrm{a}}$ & $15.05 \pm 0.65^{\mathrm{b}}$ & $25.18 \pm 0.48^{\mathrm{a}}$ & $23.82 \pm 1.71^{\mathrm{a}}$ \\
Hardness (kg) & $0.02 \pm 0.001^{\mathrm{c}}$ & $0.02 \pm 0.0001^{\mathrm{c}}$ & $0.02 \pm 0.0002^{\mathrm{c}}$ & $0.045 \pm 0.004^{\mathrm{b}}$ & $0.075 \pm 0.001^{\mathrm{a}}$ \\
Crispness (kg.sec) & $1.28 \pm 0.13^{\mathrm{c}}$ & $2.95 \pm 0.19^{\mathrm{b}}$ & $3.32 \pm 0.22^{\mathrm{b}}$ & $4.09 \pm 0.01^{\mathrm{a}}$ & $3.16 \pm 0.21^{\mathrm{b}}$ \\
\hline
\end{tabular}

Mean value with same superscript letter within the same showed no significant different $(\mathrm{p}<0.05)$. 


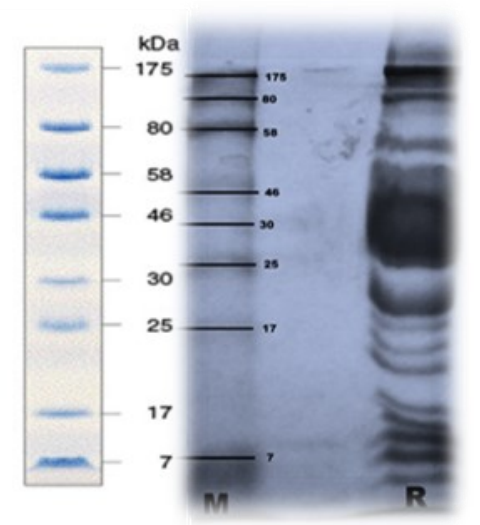

Figure 2. SDS PAGE analysis of extracted Toothpony FPH by enzymatic hydrolysis

\subsection{Functional groups}

FTIR transmission spectrum of Toothpony fish protein hydrolysate powder is demonstrated in Figure 3. Amide I and amide II bands of Toothpony FPH appeared at around 1654 and $1535 \mathrm{~cm}^{-1}$, respectively. Amide I and amide II bands at $1700-1600$ and $1560-1500 \mathrm{~cm}^{-1}$ were reported by Benjakul and Morrisey (2009). The amide I vibration mode is primarily a $\mathrm{C}=\mathrm{O}$ stretching vibration coupled to minor contributions from the $\mathrm{CN}$ stretch, $\mathrm{CCN}$ deformation and in-plane $\mathrm{NH}$ bending modes (Lavialle et al., 1982; Bandekar, 1992). The amide I vibration is hardly affected by the nature of the side chain. It depends however on the secondary structure of the backbone and is, therefore, the amide vibration that is most commonly used for secondary structure analysis (Barth, 2007). Amide II derives mainly from in-plane $\mathrm{NH}$ bending and $\mathrm{CN}$ stretching vibration and shows less protein conformational sensitivity compared with amide I (Kong and Yu, 2007). The amide II band is generally considered to be much more sensitive to hydration than to secondary structure change (Wellner et al., 1996). Amide III band of protein hydrolysate was detected at $1264 \mathrm{~cm}^{-1}$ which was associated with loss of triple-helix state of the molecules and transformation of $\alpha$-helical to random coil structure due to denaturation of protein
(Muyonga et al., 2004). The amide III vibration mode is the in-phase combination of the $\mathrm{NH}$ bending and the $\mathrm{CN}$ stretching vibration with small contributions from the $\mathrm{CO}$ in plane bending and the $\mathrm{CC}$ stretching vibration. In polypeptides, the composition of this mode is more complex, since it depends on side-chain structure and since $\mathrm{NH}$ bending contributes to several modes in the $1400-$ to $1200-\mathrm{cm}^{-1}$ region (Barth, 2007).

\subsection{Oil uptake}

Table 3 displays the oil binding capacity information for Toothpony fish protein hydrolysate, calculated as 1.9 $\mathrm{g}$ oil / g protein. The low oil binding capacity obtained in Toothpony FPH can be explained by its low MW (10$25 \mathrm{kDa}$ ) as shown in Table 3 . He et al. (2016) reported that oil-binding capacity of FPH was affected by its MW properties and distributions. FPH with the molecular weight that is smaller than $10 \mathrm{kDa}$ possesses the lowest oil-binding capacity compared to FPH with higher molecular weight. An interesting study that investigated the oil binding capacity of Codfish and Bluefish processing co-products protein hydrolysates found that $1.2 \mathrm{~g}$ oil/ $\mathrm{g}$ protein and $1.9 \mathrm{~g}$ oil/ $\mathrm{g}$ protein, respectively (Slizyte et al., 2005; Geirsdottir et al., 2011), which were in agreement with this study. However, the data collected in this study was lower than Yellowtail Kingfish FPH produced by Alcalase extraction (12.14 g oil/ g FPH) (He et al., 2013).

The mechanism for oil binding capacity is attributed to the combination of physical entrapment of oil and the hydrophobicity of the material (He et al., 2013). Hydrophobicity of fish protein hydrolysates develops because hydrolysis cleaves the protein chain so more internal hydrophobic groups were exposed (Kristinsson and Rasco, 2000). However, the excessive hydrolysation compromises the integrity of the protein structure and results in the degradation of the protein network formed to entrap oil (He et al., 2013). The low oil binding capacity of Toothpony FPH was in agreement with its high DH (98.02\%) as shown in Table 3. Gbogouri et al.

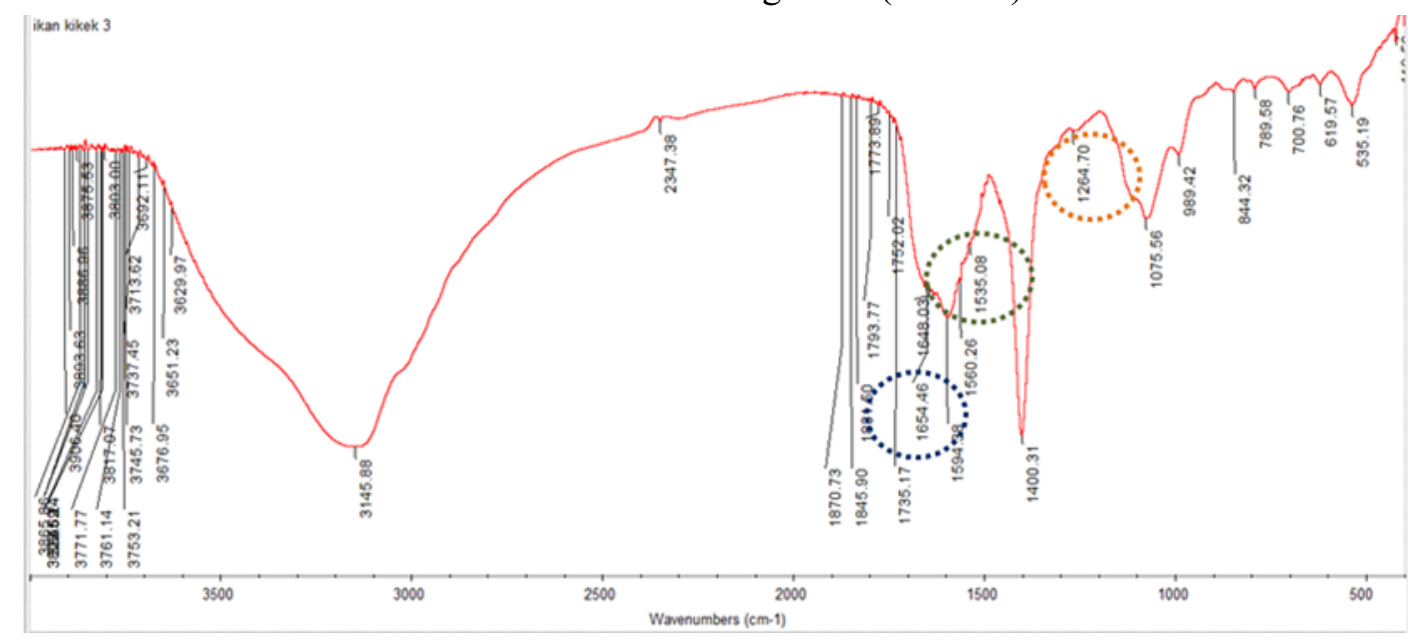

Figure 3. FTIR transmission spectrum of Toothpony FPH powder 
(2004) observed a decrease of oil binding capacity in salmon by-products hydrolysates with increasing $\mathrm{DH}$.

Oil uptake of deep-fat-fried squid batter crust incorporated with $0 \%, 2 \%, 4 \%, 6 \%, 8 \%$ Toothpony FPH were also shown in Table 3. The fat uptake of deep-fatfried squid batter crust incorporated with 4\% Toothpony FPH was significantly the lowest (15.05\%) among the samples. This indicated that $4 \%$ of Toothpony FPH is the optimum amount to be incorporated in batter in order to reduce oil uptake significantly. Fat uptake of batter crust incorporated with $2 \%, 6 \%$ and $8 \%$ of Toothpony FPH were negligible when compared with the fat content of the control sample $(27.22 \%)$. However, the fat content of the control sample was found to be the highest than that of other samples. This was probably due to incorporation of Toothpony FPH in the batter helps reduce oil uptake in deep-fried food products by its low oil binding capacity property ( $1.9 \mathrm{~g}$ oil/g protein). Lower oil-binding capacity was generally associated with lower fat uptake. He et al. (2015) also observed that the fat content of deep -fried fish with batter coating was reduced using Yellowtail Kingfish FPH. Fat uptake reduction of deepfried food using other protein-based ingredients in batter coating has also been reported before. Albert and Mittal (2002), for instance, found that batter coating systems of soy protein could reduce the fat uptake of deep-fried cereal products by up to $99.8 \%$. Garcia et al. (2002) compared the effects of various cellulose derivatives and additionally the sorbitol effect on selected cellulose derivatives in French fries and found that a fat uptake reduction of $41 \%$ could be achieved.

\subsection{Texture profile analysis}

Hardness (kg) and crispness (kg.sec) of deep-fatfried squid were demonstrated in Table 3. Texture of battered products involves many characteristics, foremost of which is hardness, which describes the textural attributes of the substrate. Deep-fat-fried squid incorporated with $2 \%, 4 \%, 6 \%, 8 \%$ of Toothpony $\mathrm{FPH}$ were harder than deep-fat-fried squid incorporated with $0 \%$ of Toothpony FPH. This could be due to incorporation of Toothpony FPH has increased hardness of fried samples. The final result was the increase in the hardness value. Deep-fat-fried squid without Toothpony FPH showed the least crispness (1.28 kg.sec) among all samples. Incorporation of Toothpony FPH could be the cause of increased crispness in deep-fat-fried squid batter crust. As the protein level increased, there was a gradual increase in roughness of texture and brittleness of the fried coating. This rough, brittle texture translated into a high crispness value (Kulp and Loewe, 2011). Mohamed et al. (1998) observed that the addition of protein, ovalbumin to a batter improved crispness. However, excess protein in batter may reduce crispness by emulsifying more oil and water into the fried product. This is in agreement with the decrease of crispness in sample with $8 \%$ of Toothpony FPH $(3.16 \mathrm{~kg} . \mathrm{sec})$ compared to sample with $6 \%$ of Toothpony FPH (4.09 kg.sec).

\subsection{Colour analysis}

Figure 4 exhibits the effect of different amount of Toothpony FPH on colour development of deep-fat-fried squid was examined in terms of Hunter $L^{*} a^{*} b^{*}$ values. Different amount of Toothpony FPH was added into batter formulation to coat deep-fat-fried squid better. Deep-fat-fried squid developed a yellowish-brown colour when they were fried. The deep-fat-fried squid incorporated with $0 \%$ Toothpony FPH has significantly lower $a^{*}$ value compared to deep-fat-fried squid incorporated with $2 \%, 4 \%, 6 \%$ and $8 \%$ of Toothpony FPH. It was assumed that the presence of FPH in batter has caused the significantly higher $\mathrm{a}^{*}$ values in deep-fatfried squid. A light golden tone was the benchmark colour for determining the end of the final frying process (Ansarifar et al., 2012). The non-significant trend of $b^{*}$ values among samples might be due to the consistent frying time (3 mins) carried out in this study. Ansarifar et al. (2012) have reported that $b^{*}$ value of deep-fat-fried crust decreased with frying time.

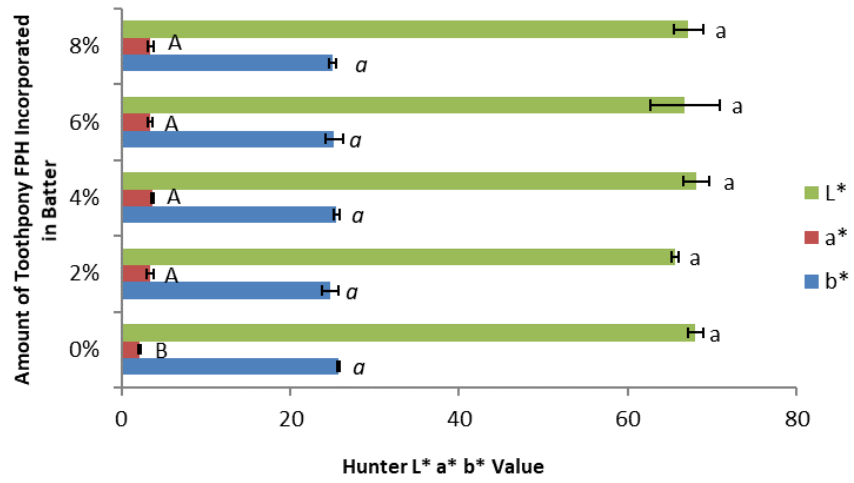

Figure 4. Colour profile of deep-fat-fried squid incorporated with different amount of Toothpony FPH. Mean value with same superscript letter showed no significant different $(p<0.05)$. Superscripts (a) were compared among $L^{*}$ values. Superscripts (A, B) were compared among $a^{*}$ values. Superscripts (a) were compared among $b^{*}$ values.

\subsection{Sensory evaluation}

The results of sensory evaluation of deep-fat-fried squid incorporated with $0 \%, 2 \%, 4 \%, 6 \%$, and $8 \%$ of Toothpony FPH is depicted in Table 4 . The mean score for acceptability of colour for deep-fat-fried squid incorporated with $2 \%$ of Toothpony FPH was significantly the lowest (4.13) among all samples. However, in colour analysis, deep-fat-fried squid incorporated with $2 \%$ of Toothpony FPH showed no significant difference with other samples as shown in 
Table 4. Sensory scores of deep-fat-fried squid incorporated with different amount of Toothpony FPH

\begin{tabular}{cccccc}
\hline Sample & Colour & Crispness & Oiliness & Taste & Overall acceptability \\
\hline A & $5.20 \pm 1.45^{\mathrm{a}}$ & $5.30 \pm 1.64^{\mathrm{a}}$ & $4.47 \pm 1.52^{\mathrm{ab}}$ & $4.57 \pm 1.36^{\mathrm{ab}}$ & $4.53 \pm 1.15^{\mathrm{b}}$ \\
B & $4.13 \pm 1.45^{\mathrm{b}}$ & $4.93 \pm 1.63^{\mathrm{a}}$ & $4.10 \pm 1.40^{\mathrm{ab}}$ & $4.90 \pm 1.42^{\mathrm{ab}}$ & $4.63 \pm 1.25^{\mathrm{ab}}$ \\
C & $4.60 \pm 1.67^{\mathrm{a}}$ & $5.33 \pm 1.53^{\mathrm{a}}$ & $4.63 \pm 1.52^{\mathrm{a}}$ & $4.33 \pm 1.58^{\mathrm{b}}$ & $4.43 \pm 1.31^{\mathrm{b}}$ \\
D & $4.70 \pm 1.73^{\mathrm{a}}$ & $5.00 \pm 1.53^{\mathrm{a}}$ & $3.77 \pm 1.69^{\mathrm{b}}$ & $4.60 \pm 1.70^{\mathrm{ab}}$ & $4.57 \pm 1.48^{\mathrm{ab}}$ \\
E & $5.27 \pm 1.34^{\mathrm{a}}$ & $5.37 \pm 1.25^{\mathrm{a}}$ & $4.80 \pm 1.70^{\mathrm{a}}$ & $5.27 \pm 1.26^{\mathrm{a}}$ & $5.20 \pm 1.05^{\mathrm{a}}$ \\
\hline
\end{tabular}

$\mathrm{A}=0 \%, \mathrm{~B}=2 \%, \mathrm{C}=4 \%, \mathrm{D}=6 \%$, and $\mathrm{E}=8 \%$. Mean value with same superscript letter within column showed no significant different $(\mathrm{p}<0.05)$.

Table 4. The colour acceptability was increased as the amount of Toothpony FPH incorporated in deep-fat-fried squid batter crust increased. This could be explained by higher Toothpony FPH amount has increased the affinity towards colour acceptability. Golden colour, between yellow and brown developed by coated foods when they are fried, is a characteristic that consumers normally consider very attractive (Ansarifar, 2012). The acceptability of oiliness for deep-fat-fried squid incorporated with $6 \%$ of Toothpony FPH was the lowest (3.77) among all samples. Panellists perceived that high amount of Toothpony FPH (6\%) in deep-fat-fried squid batter have caused undesirable oiliness. The amount of oil uptake has generally been related to the amount of moisture lost (Basuny et al., 2009). Protein can hydrate/ hold water and possess emulsifying ability due to their hydrophilic and lipophilic side chains (Mohamed et al., 1998). Food product that contains higher initial moisture content results in an increased oil uptake, since water evaporation defines the volume of the oil reservoir through the empty spaces, as it leaves the structure (Basuny et al., 2009).

\section{Conclusion}

The outcome of this study shows the potential usage of protein hydrolysate from Toothpony edible parts for the production batter formulation which is efficient in the reduction of oil uptake. The protein hydrolysate contained $16.08 \%$ of protein, $4.41 \%$ of fat and $77.51 \%$ of moisture. The deep-fat-fried squid incorporated with $0 \%$ of Toothpony FPH showed the least hardness and crispness compared to deep-fat-fried squid incorporated with $2 \%, 6 \%$ and $8 \%$ of Toothpony FPH. Oil uptake of batter crust incorporated with $2 \%, 6 \%$ and $8 \%$ of Toothpony FPH showed no significant differences when compared with the fat content of the control sample $(27.22 \%)$. In sensory evaluation, deep-fat-fried squid incorporated with $8 \%$ of Toothpony FPH showed the highest acceptance in all attributes, which were colour, crispness, oiliness, taste and overall acceptability.

\section{Conflict of Interest}

The authors declare that there is no conflict of interest in conducting this study.

\section{Acknowledgments}

This research was supported by Universiti Malaysia Terengganu. The authors would like to thank the UMT's central lab and the Faculty of Fisheries and Food Science (FPSM) for the facilities provided to conduct the study.

\section{References}

Albert, S. and Mittal, G.S. (2002). Comparative evaluation of edible coatings to reduce fat uptake in a deep-fat fried cereal product. Food Research International, 35(5), 445-458. https:// doi.org/10.1016/S0963-9969(01)00139-9

Ansarifar, E., Mohebbi, M. and Shahidi, F. (2012). Studying some physicochemical characteristics of crust coated with white egg and chitosan using a deep-fried model system. Food and Nutrition Sciences, 3(5), 685-692. https://doi.org/10.4236/ fns.2012.35093.

AOAC. (2012). Official methods of analysis, Association of official analytical chemist. $19^{\text {th }}$ ed., Washington D.C., USA: AOAC

Bandekar, J. (1992). Amide modes and protein conformation. Biochimica et Biophysica Acta Protein Structure and Molecular Enzymology, 1120 (2), 123-143. https://doi.org/10.1016/0167-4838(92) 90261-B

Barth, A. (2007). Review Infrared spectroscopy of proteins. Biochimica Et Biophysica Acta, 1767(9), 1073-1101. j.bbabio.2007.06.004

Basuny, A.M., Mostafa, D.M. and Shaker, A.M. (2009). Relationship between chemical composition and sensory evaluation of potato chips made from six potato varieties with emphasis on the quality of fried sunflower oil. World Journal of Dairy and Food Sciences, 4(2), 193-200.

Benjakul, S. and Morrissey, M.T. (1997). Protein hydrolysates from Pacific whiting solid wastes. Journal of Agricultural and Food Chemistry, 45(9), 3423-3430. https://doi.org/10.1021/jf970294g 
Chalamaiah, M., Kumar, B.D., Hemalatha, R. and Jyothirmayi, T. (2012). Fish protein hydrolysates: Proximate composition, amino acid composition, antioxidant activities and applications: A review. Food Chemistry, 135(4), 3020-3038. https:// doi.org/10.1016/j.foodchem.2012.06.100

Chalamaiah, M., Rao, G.N., Rao, D.G. and Jyothirmayi, T. (2010). Protein hydrolysate from Merige (Cirrhinus mrigala) egg and evaluation of their functional properties. Food Chemistry, 120(3), 652657. https://doi.org/10.1016/j.foodchem.2009.10.057

Dogan, S.F., Sahin, S. and Sumnu, G. (2005). Effects of batters containing different protein types on the quality of deep-fat-fried chicken nuggets. European Food Research and Technology, 220(5-6), 502-508. https://doi.org/10.1007/s00217-004-1099-7

Durga Maha Lakshmi, C.H.N., Deva Prasad Raju, B., Madhavi, T. and John Sushma, N. (2014). Identification of bioactive compounds by FTIR analysis and in vitro antioxidant activity of $C$. ternatea leaf and flower extracts. Indo American Journal of Pharmaceutical Research, 4(9), 38943903.

Garcia, M.A., Ferrero C., Bertola, N., Martino, M. and Zaritzky, N. (2002). Edible coating from cellulose derivatives to reduce oil uptake in fried products. Innovative Food Science and Emerging Technologies, 3(4), 391-397. https://doi.org/10.1016/ s1466-8564(02)00050-4

García, M., Bifani, V., Campos, C., Martino, M.N., Sobral, P., Flores, S. and Menegalli, F. (2008). Edible Coating as an Oil Barrier or Active System. Food Engineering Series., p. 225-241. New York, USA: Springer. https://doi.org/10.1007/978-0-38775430-7_12

Gbogouri, G.A., Linder, M., Fanni, J. and Parmentier, M. (2004). Influence of hydrolysis degree on the functional properties of Salmon by-product hydrolysates. Journal of Food Science, 69(8), 615622. 2621.2004.tb09909.x

Geirsdottir, M.S., Sigurgisladottir, S., Hamaguchi, P.Y., Thorkelsson, G., Johannsson, R., Kristinsson, H. G. and Kristjansson, M.M. (2011). Enzymatic hydrolysis of Blue whiting (Micromesistius poutassou); functional and bioactive properties. Journal of Food Science, 76(1), C14-C20. https:// doi.org/10.1111/j.1750-3841.2010.01877.x.

Hasan, M.R. and Halwart, M. (2009). Fish as feed inputs for aquaculture: Practices, sustainability and implications.

Harun, Z., Amiza, M.A., Sarbon, N.M. and Zainol,
M.K.M. (2017). Optimisation of enzymatic protein hydrolysis of Mud Crab (Scylla sp.) to obtain maximum Angiotensin-Converting enzyme inhibitory (ACEI) activity using response surface methodology. Malaysian Applied Biology, 46(3), 3340.

Hau, E.H., Amiza, M.A., Mohd Zin, Z. and Zainol, M.K. (2018). The properties, compositions and qualities of Yellowstripe scad (Selaroides leptolepis) and its liquid protein hydrolysate based on different enzyme concentrations, hydrolysis time and choice of buffer. International Food Research Journal, 25(3), 11741180.

He, S., Franco, C. and Zhang, W. (2013). Functions, applications and production of protein hydrolysates from fish processing co-products (FPCP). Food Research International, 50(1), 289-297. https:// doi.org/10.1016/j.foodres.2012.10.031

He, S., Franco, C. and Zhang, W. (2015). Fish Protein Hydrolysates: Application in Deep-Fried Food and Food Safety Analysis. Journal of Food Science, 80 (1), E108-E115. https://doi.org/10.1111/17503841.12684

He, S., Nguyen, T.T., Su, P. and Zhang, W. (2016). Protein hydrolysates produced from rock lobster (Jasus edwardsii) Head: Emulsifying capacity and food safety. Food Science and Nutrition, 4(6), 869877. https://doi.org/10.1002/fsn3.352.

Hoyle, N.T. and Merrltt, J.H. (1994). Quality of Fish Protein Hydrolysates from Herring (Clupea harengus). Journal of Food Science, 59(1), 76-79. https://doi.org/10.1111/j.1365-2621.1994.tb06901.x

Klomklao, S., Kishimura, H. and Benjakul, S. (2013). Use of viscera extract from hybrid catfish (Clarias macrocephalus, Clarias gariepinus) for the production of protein hydrolysate from toothed ponyfish (Gazza minuta) muscle. Food Chemistry, 136 (2), 1006-1012. https://doi.org/10.1016/ j.foodchem.2012.09.037

Kong, J. and Yu, S. (2007). Fourier transform infrared spectroscopic analysis of protein secondary structures. Acta Biochimica et Biophysica Sinica, 39 (8), 549-559. https://doi.org/10.1111/j.17457270.2007.00320.x.

Kristinsson, H.G. and Rasco, B.A. (2000). Fish protein hydrolysates: Production, biochemical and functional properties. Critical Reviews in Food Science and Nutrition, 40, 43-81. https:// doi.org/10.1080/10408690091189266

Kulp, K. and Loewe, R. (2011). Batters and breadings in food processing. $2^{\text {nd }}$ ed. St. Paul, Minnesota, USA: American Association of Cereal Chemists. 
Lavialle, F., Adams, R.G. and Levin, I.W. (1982). Infrared spectroscopic study of the secondary structure of Melittin in water, 2-chloroethanol, and phospholipid bilayer dispersions. Biochemistry, 21 (10), 2305-2312. https://doi.org/10.1021/ bi00539a006

Liaset, B., Lied, E. and Espe, M. (2000). Enzymatic hydrolysis of by-products from the fish-filleting industry; chemical characterisation and nutritional evaluation. Journal of the Science of Food and Agriculture, 80(5), 581-589. https://doi.org/10.1002/ (sici)1097-0010(200004)80:5<581::aidjsfa578>3.0.co;2-i

Mahmoodani, F., Ghassem, M., Babji, A.S., Yusop, S.M. and Khosrokhavar, R. (2014). ACE inhibitory activity of Pangasius catfish (Pangasius sutchi) skin and bone gelatin hydrolysate. Journal of Food Science and Technology, 51(9), 1847-56. https:// doi.org/10.1007/s13197-012-0742-8

Mohamed, S., Hamid, N.A., and Hamid, M.A. (1998). Food components affecting the oil absorption and crispness of fried batter. Journal of Science and Food Agriculture, 78(1), 39-45. https:// doi.org/10.1002/(SICI)1097-0010(199809)

78:1<39::AID-JSFA82>3.0.CO;2-G

Muyonga, J.H., Cole C.G.B. and Duodu K.G. (2004). Fourier transform infrared (FTIR) spectroscopic study of acid soluble collagen and gelatin from skins and bones of young and adult Nile perch (Lates niloticus). Food Chemistry, 86(3), 325-332. https:// doi.org/10.1016/j.foodchem.2003.09.038

Nesse, K.O., Nagalakshmi, A.P., Marimuthu, P. and Singh, M. (2011). Efficacy of a fish protein hydrolysate in malnourished children. Indian Journal of Clinical Biochemistry, 26(4), 360- 365. https://doi.org/10.1007/s12291-011-0145-z

Pedreschi, F. and Moyano, P. (2005). Effect of predrying on texture and oil uptake of potato chips. LWT-Food Science and Technology, 38(6), 599-604. https://doi.org/10.1016/j.lwt.2004.08.008

Pedreschi, F. (2012). Frying of potatoes: Physical, chemical, and microstructural changes. Drying Technology, 30(7), 707-725. https://doi.org/10.1080/ 07373937.2012 .663845

Perschbacher, P.W. and Stickney, R.R. (2017). Tilapia in intensive co-culture. Chichester, UK: John Wiley and Sons.

Roslan, J., Yunos, K.F.M., Abdullah, N. and Kamal, S.M.M. (2014). Characterization of fish protein hydrolysate from Tilapia (Oreochromis nloticus) byproduct. Agriculture and Agricultural Science Procedia, 2, 312-319. https://doi.org/10.1016/ j.aaspro.2014.11.044

Slizyte, R., Dauksas, E., Falch, E., Storro, I. and Rustad, T. (2005) Yield and composition of different fractions obtained after enzymatic hydrolysis of cod (Gadusmorhua) by-products. Process Biochemistry, 40(3-4), 1415-1424. https://doi.org/10.1016/ j.procbio.2004.06.033.

Souissi, N., Bougatef, A., Triki-ellouz, Y. and Nasri, M. (2007). Biochemical and Functional Properties of Sardinella (Sardinella aurita) By-Product Hydrolysates. Food Technology and Biotechnology, 45(2), 187-194.

Sugiyama, K., Egawa, M., Onzuka, H. and Oba, K. (1991) Characteristics of sardine muscle hydrolysates prepared by various enzymic treatments. Nion Suisan Gakkaishi, 57(3), 475-479. https://doi.org/ 10.4172/1948-5948.1000110

Venuste, M., Zhang, X., Shoemaker, C.F., Karangwa, E., Abbas, S. and Kamdem, P.E. (2013). Influence of enzymatic hydrolysis and enzyme type on the nutritional and antioxidant properties of pumpkin meal hydrolysates. Food and Function, 4(5), 811820. https://doi.org/10.1039/c3fo30347k

Wasswa, J., Tang, J., Gu, X. and Yuan, X. (2007). Influence of the extent of enzymatic hydrolysis on the functional properties of protein hydrolysate from grass carp (Ctenopharyngodon idella) skin. Food Chemistry, 104(4), 1698-1704. https:// doi.org/10.1016/j.foodchem.2007.03.044

Wellner, N., Belton, P.S. and Tatham, A.S. (1996). Fourier transform IR spectroscopic study of hydration-induced structure changes in the solid state of x-gliadins. Biochemical Journal, 319(3), 741-747. https://doi.org/10.1042/bj3190741

Zainol, M.K, Mohd Zin, Z., Linforth, R.S.T. and Scott, D.J. (2014). Overexpression, Extraction, Purification and Characterisation of DppA from Escherichia coli. Journal of Biochemistry, Microbiology and Biotechnology, 2(2), 40-46. 